\title{
The laboratory diagnosis of bacterial vaginosis
}

\author{
Deborah Money MD FRCSC
}

D Money. The laboratory diagnosis of bacterial vaginosis. Can J Infect Dis Med Microbiol 2005;16(2):77-79.

\begin{abstract}
Bacterial vaginosis (BV) is an extremely common health problem for women. In addition to the troublesome symptoms often associated with a disruption in the balance of vaginal flora, BV is associated with adverse gynecological and pregnancy outcomes. Although not technically a sexually transmitted infection, BV is a sexually associated condition. Diagnostic tests include real-time clinical/microbiological diagnosis, and the current gold standard, the standardized evaluation of morphotypes on Gram stain analysis. The inappropriate use of vaginal culture can be misleading. Future developments into molecularbased diagnostics will be important to further understand this complex endogenous flora disruption.
\end{abstract}

Key Words: Bacterial vaginosis; Infection; Vaginitis

$\mathrm{B}$ acterial vaginosis (BV) is one of the most common lower genital tract conditions, occurring in $35 \%$ of women attending sexually transmitted infection (STI) clinics, $15 \%$ to $20 \%$ of pregnant women, and $5 \%$ to $15 \%$ of women attending gynecology clinics (1). Clinical features were first described by Gardner and Dukes (2), and range from asymptomatic to an increased thin vaginal discharge with or without a fishy odour. There are a number of pregnancy and/or gynecological complications associated with BV (3). Specifically, BV has been associated with both STI and nonchlamydial, nongonococcal pelvic inflammatory disease $(4,5)$. Of importance, BV may be associated with an increased risk of acquisition of HIV (6-8). In addition, BV has been associated with infections following termination of pregnancy, insertion of intrauterine devices, and hysterectomy, both vaginal and abdominal (7-10). This syndrome has been associated with serious pregnancy complications, including premature rupture of the membranes, preterm delivery and postpartum endometritis (11-16). Given the varied and important conditions associated with this common disorder, an accurate and clearly understood diagnosis is critical.

The diagnosis of BV has been problematic due to its complex polymicrobial nature (17). Vaginal cultures were often used as a primary laboratory test in the past, but this was found to be of little value. Organisms classically associated with BV, including Gardnerella vaginalis, can be recovered on laboratory media from $83 \%$ to $94 \%$ of women with clinical signs of BV,

\section{Diagnostic de la vaginose bactérienne en laboratoire}

La vaginose bactérienne est un problème de santé extrêmement courant chez la femme. En plus des symptômes ennuyeux souvent associés à ce déséquilibre de la flore vaginale, la vaginose bactérienne est associée à des problèmes gynécologiques et de fertilité. Bien qu'il ne s'agisse pas à proprement parler d'une infection transmissible sexuellement, la vaginose bactérienne est une maladie qui a une composante sexuelle. Les analyses diagnostiques reposent notamment sur l'examen clinique et les tests microbiologiques en temps réel, et sur la norme diagnostique actuelle, l'analyse standardisée des morphotypes par coloration de Gram. L'utilisation inappropriée de la culture vaginale est parfois trompeuse, c'est pourquoi les développements à venir au chapitre du diagnostic moléculaire seront importants si nous voulons mieux comprendre cette perturbation endogène complexe de la flore.

but are also recovered in $36 \%$ to $55 \%$ of asymptomatic women without clinical features (18). In addition, culture and identification of other bacteria from vaginal specimens such as Bacteroides species, Peptostreptococcus species and Mycoplasma hominis has been evaluated, and found to be specific but insensitive and costly to the laboratory (19). Other anaerobic bacteria strongly associated with BV, such as Mobiluncus species, are very difficult to recover by culture (20). At the same time, normal vaginal lactobacilli are significantly reduced or absent. As a consequence, clinical diagnosis must rely on methods that identify proportions of bacterial morphotypes in the vaginal specimen (21).

\section{SPECIMEN CHOICE, COLLECTION AND TRANSPORT}

The collection of material for diagnosis is ideally performed during a comprehensive pelvic examination using a speculum. At the time of speculum examination, an evaluation of the nature of the discharge is made by the clinician, and a specimen from the lateral vaginal wall and posterior fornix can be taken with a sterile swab. The classical BV discharge is thin, homogeneous and grey/yellow in colour. However, absence of the classic discharge does not rule out disturbed vaginal flora. In certain clinical circumstances, where STI pathogens have been ruled out and there is no other reason for a speculum examination, the swab can be taken as a blind vaginal swab taken by the clinician or the patient (22). Two basic methods

Maternal $\mathcal{E}$ Fetal Medicine, Department of Obstetrics and Gynecology, University of British Columbia, Vancouver, British Columbia

Correspondence: Dr Deborah Money, University of British Columbia, 2H30 - 4500 Oak Street, Vancouver, British Columbia

V6H 2N1. Telephone 604-875-2665, fax 604-875-2987, e-mail dmoney@cw.bc.ca 
TABLE 1

Scoring system (0-10) for the Gram-stained vaginal smears

\begin{tabular}{lccc}
\hline Score & $\begin{array}{c}\text { Lactobacillus } \\
\text { morphotypes }\end{array}$ & $\begin{array}{c}\text { Gardnerella and } \\
\text { Bacteroides species } \\
\text { morphotypes }\end{array}$ & $\begin{array}{c}\text { Curved Gram- } \\
\text { variable rods }\end{array}$ \\
\hline 0 & $4+$ & 0 & 0 \\
1 & $3+$ & $1+$ & $1+$ or $2+$ \\
2 & $2+$ & $2+$ & $3+$ or $4+$ \\
3 & $1+$ & $3+$ & \\
4 & 0 & $4+$ & \\
\hline $1+\leq 1 / 1000 \times$ field; $2+=$ & $1-5 / 1000 \times$ field; $3+=6-30 / 1000 \times$ field; \\
$4+\geq 30 / 1000 \times$ field &
\end{tabular}

of diagnostic testing can be used: laboratory based and clinical 'bedside' testing. For the purposes of laboratory based testing, the swab can be placed in a standard bacterial culture transport medium to maintain moistness or can be smeared onto a slide and air dried for later Gram stain. Transportation for either of these transport systems (culturette or dried slide) can be at room temperature or $4^{\circ} \mathrm{C}$.

\section{DIAGNOSTIC TESTS}

Performance related to specimen type, and diagnostic test limitations

There are two main categories of diagnostic tests for BV: clinical criteria and laboratory-based testing.

The most widely accepted clinical criteria are 'Amsel's criteria' (23). This clinical diagnosis requires that three of the following four criteria be met: first, a vaginal $\mathrm{pH}$ of greater than $\mathrm{pH} 4.5$; second, the presence of clue cells in the vaginal fluid; third, a milky, homogeneous vaginal discharge; and finally, the release of an amine (fishy) odour after addition of $10 \%$ potassium hydroxide to the vaginal fluid (23). The $\mathrm{pH}$ can be determined directly with the use of $\mathrm{pH}$ sticks placed on the vaginal wall or with the use of a swab which is touched on $\mathrm{pH}$ paper in the range covering $\mathrm{pH} 4.0$ to $\mathrm{pH} 6.5$. The swab is then extracted into $0.2 \mathrm{~mL}$ of physiological saline either on a glass slide or in a test tube; a drop of the extract is then placed on a glass slide. A drop of $10 \%$ potassium hydroxide is placed on another glass slide. The swab is then stirred in the $10 \%$ potassium hydroxide and immediately evaluated for the presence of a fishy odour. Both drops are then covered with a coverslip and examined at $400 \times$ magnification with a light microscope. Clue cells are identified as vaginal epithelial cells with such a heavy coating of bacteria that the peripheral borders are obscured. If three of four criteria are met, then a clinical diagnosis of BV can be made.

For the laboratory testing method, the preferred specimen is an unfixed vaginal smear sent to the laboratory to be Gram stained by standard methods. The stained slide is read, and the number of morphotypes are evaluated based on a standardized scoring method. The diagnostic criteria developed by Spiegel et al (24) and later modified by Nugent et al (25) has been a well-reproduced standardized Gram stain scoring method (Table 1).

In the methodology by Nugent et al (25), the swab was obtained from the lateral vaginal wall and rolled on a glass slide. The smears were then heat fixed and Gram stained using safranin as the counterstain. The smear was then evaluated for the following morphotypes under oil immersion (1000x magnification): large Gram-positive rods (lactobacillus morphotypes), small Gram-variable rods ( $\mathrm{G}$ vaginalis morphotypes), small Gram-negative rods (Bacteroides species morphotypes), curved Gram-variable rods (Mobiluncus species morphotypes) and Gram-positive cocci. Although Gram-positive cocci are not part of the scoring system, some laboratories will report them if they are present in significant numbers. Increased numbers of Gram-positive cocci are not part of the pattern of the normal vaginal flora. Of note, the Nugent scoring system yielded an improvement in intercentre agreement compared with the previously published criteria (24), but a standardized scoring method is the most important approach.

A score of zero to three is considered to be normal, four to six is considered intermediate, and seven to ten is defined as $\mathrm{BV}$. Intermediate vaginal flora is reported to the clinician for management based on the clinical context. Thirty two per cent of patients with an intermediate score will proceed to BV and 30\% to normal flora. Many authors feel that an intermediate score should be included as abnormal given the high rate of transition to BV. The decision to recheck or treat is based on the clinical risk of proceeding to BV (26). This scoring system correlates well with clinical disease (18). The clinical methodology is useful because it allows for an immediate answer in certain urgent clinical situations, but the Gram stain method appears to be more accurate (27-29). However, in pregnancy in the setting of rupture of membranes, it has good negative predictive value $(83 \%)$ but poor sensitivity (30).

There have been alternative diagnostic methods suggested, but none are currently better than the standardized Gram stain methodology. The use of gas-liquid chromatography, vaginal cultures and liquid preparation Papanicolaou smears have been proposed as alternative methods of diagnosis due to the practical advantage of sampling and common transportation to the laboratory. At the time of writing, this has only been done in research settings and would require significant changes in the approach to reading smears. There are variable reports of a general lack of sensitivity but reasonable specificity $(31,32)$. To date, nucleic acid techniques have not proven to be useful for the clinical diagnosis of the complex microbial imbalance, but may prove useful in the future (33). Many researchers are exploring a genetic basis for evaluation of the complex microbial flora of the vagina; there is some preliminary promise in the use of chaperonin 60-based evaluations, while others are using an RNA-based approach. None of these techniques are currently useful in the clinical setting due to complexity and cost, but they may be highly valuable in the future $(34,35)$. In summary, the most useful current diagnostic method is the vaginal Gram stain.

\section{Proficiency and quality assurance}

The laboratory diagnosis of BV is mainly achieved by microscopy. Quality assurance should therefore ensure good practice in preparing and reading Gram stains, competency in the microscopists, and correct maintenance and set up of the microscopes. The laboratory should have ongoing communication with its clinicians to ensure that the smear being submitted is vaginal and not cervical. This should be indicated on the specimen requisition. A negative result for BV on a cervical smear could lead to inappropriate patient management. Good practice requires that the report on the Gram smear should mention the presence or absence of yeast cells. 


\section{REFERENCES}

1. Eschenbach DA. History and review of bacterial vaginosis. Am J Obstet Gynecol 1993;169:441-5.

2. Gardner HL, Dukes CD. Haemophilus vaginalis vaginitis: A newly defined specific infection previously classified non-specific vaginitis. Am J Obstet Gynecol 1955;69:962-76.

3. Schwebke JR. Gynecologic consequences of bacterial vaginosis. Obstet Gynecol Clin North Am 2003;30:685-94.

4. Eschenbach DA, Hillier S, Critchlow C, Stevens C, DeRouen T, Holmes KK. Diagnosis and clinical manifestations of bacterial vaginosis. Am J Obstet Gynecol 1988;158:819-28.

5. Faro S, Martens M, Maccato M, Hammill H, Pearlman M. Vaginal flora and pelvic inflammatory disease. Am J Obstet Gynecol 1993;169:470-4.

6. Taha TE, Hoover DR, Dallabetta GA, et al. Bacterial vaginosis and disturbances of vaginal flora: Association with increased acquisition of HIV. AIDS 1998;12:1699-706.

7. Sewankambo N, Gray RH, Wawer MJ, et al. HIV-1 infection associated with abnormal vaginal flora morphology and bacterial vaginosis. Lancet 1997;350:546-50.

8. Martin HL, Richardson BA, Nyange PM, et al. Vaginal lactobacilli, microbial flora and risk of human immunodeficiency virus type 1 and sexually transmitted disease acquisition. J Infect Dis 1999;180:1893-8.

9. Larsson PG, Bergman B, Forsum U, Platz-Christensen JJ, Pahlson C. Mobiluncus and clue cells as predictors of PID after first-trimester abortion. Acta Obstet Gynecol Scand 1989;68:217-20.

10. Larsson PG, Platz-Christensen JJ, Forsum U, Pahlson C. Clue cells in predicting infections after abdominal hysterectomy. Obstet Gynecol $1991 ; 77: 450-2$

11. Koumans EH, Kendrick JS; CDC Bacterial Vaginosis Working Group. Preventing adverse sequelae of bacterial vaginosis: A public health program and research agenda. Sex Transm Dis 2001;28:292-7.

12. Hillier SL, Nugent RP, Eschenbach DA, et al. Association between bacterial vaginosis and preterm delivery of a low-birth-weight infant. The Vaginal Infections and Prematurity Study Group. N Engl J Med 1995;333:1737-42.

13. Krohn MA, Hillier SL, Nugent RP, et al. The genital flora of women with intraamniotic infection. Vaginal Infection and Prematurity Study Group. J Infect Dis 1995;171:1475-80.

14. Hay PE, Lamont RF, Taylor-Robinson D, Morgan DJ, Ison C, Pearson J. Abnormal bacterial colonisation of the genital tract and subsequent preterm delivery and late miscarriage. BMJ 1994;308:295-8.

15. Watts DH, Krohn MA, Hillier SL, Eschenbach DA. Bacterial vaginosis as a risk factor for post-cesarean endometritis. Obstet Gynecol 1990;75:52-8.

16. Korn AP, Bolan G, Padian N, Ohm-Smith M, Schachter J, Landers DV. Plasma cell endometritis in women with symptomatic bacterial vaginosis. Obstet Gynecol 1995;85:387-90.

17. Hillier SL, Krohn MA, Klebanoff SJ, Eschenbach DA. The relationship of hydrogen peroxide-producing lactobacilli to bacterial vaginosis and genital microflora in pregnant women. Obstet Gynecol 1992;79:369-73.

18. Hillier SL. Diagnostic microbiology of bacterial vaginosis. Am J Obstet Gynecol 1993;169:455-9.
19. Krohn MA, Hillier SL, Eschenbach DA. Comparison of methods for diagnosing bacterial vaginosis among pregnant women. J Clin Microbiol 1989;27:1266-71.

20. Roberts MC, Hillier SL, Schoenknecht FD, Holmes KK. Comparison of gram stain, DNA probe, and culture for the identification of species of Mobiluncus in female genital specimens. J Infect Dis 1985;152:74-7.

21. Spiegel CA. Bacterial vaginosis. Rev Med Micro 2002;13:43-51.

22. Morgan DJ, Aboud CJ, McCaffrey IM, Bhide SA, Lamont RF, TaylorRobinson D. Comparison of Gram-stained smears prepared from blind vaginal swabs with those obtained at speculum examination for the assessment of vaginal flora. Br J Obstet Gynaecol 1996;103:1105-8.

23. Amsel R, Totten PA, Spiegel CA, Chen KC, Eschenbach D, Holmes KK. Nonspecific vaginitis. Diagnostic criteria and microbial and epidemiologic associations. Am J Med 1983;74:14-22.

24. Spiegel CA, Amsel R, Holmes KK. Diagnosis of bacterial vaginosis by direct Gram stain of vaginal fluid. J Clin Microbiol 1983;18:170-7.

25. Nugent RP, Krohn MA, Hillier SL. Reliability of diagnosing bacterial vaginosis is improved by a standardized method of gram stain interpretation. J Clin Microbiol 1991;29:297-301.

26. Hillier SL, Krohn MA, Nugent RP, Gibbs RS. Characteristics of three vaginal flora patterns assessed by gram stain among pregnant women. Vaginal Infections and Prematurity Study Group. Am J Obstet Gynecol 1992;166:938-44.

27. Schwebke JR, Hillier SL, Sobel JD, McGregor JA, Sweet RL. Validity of the vaginal gram stain for the diagnosis of bacterial vaginosis. Obstet Gynecol 1996;88:573-6.

28. Tam MT, Yungbluth M, Myles T. Gram stain method shows better sensitivity than clinical criteria for detection of bacterial vaginosis in surveillance of pregnant, low-income women in a clinical setting. Infect Dis Obstet Gynecol 1998;6:204-8.

29. Mastrobattista JM, Bishop KD, Newton ER. Wet smear compared with Gram stain diagnosis of bacterial vaginosis in asymptomatic pregnant women. Obstet Gynecol 2000;96:504-6.

30. Core La BQ, Mastrobattista JM, Bishop K, Newton ER. Gram-stain diagnosis of bacterial vaginosis after rupture of membranes. Am J Perinatol 2000;17:315-8.

31. Davis JD, Conner EE, Clark P, Wilkinson EJ, Duff P. Correlation between cervical cytologic results and Gram stain as diagnostic tests for bacterial vaginosis. Am J Obstet Gynecol 1997;177:532-5.

32. Lamont RF, Hudson EA, Hay PE, et al. A comparison of the use of Papanicolaou-stained cervical cytological smears with Gramstained vaginal smears for the diagnosis of bacterial vaginosis in early pregnancy. Int J STD AIDS 1999;10:93-7.

33. Obata-Yasuoka M, Ba-Thein W, Hamada H, Hayashi H. A multiplex polymerase chain reaction-based diagnostic method for bacterial vaginosis. Obstet Gynecol 2002;100:759-64.

34. Zhou X, Bent SJ, Schneider MG, Davis CC, Islam MR, Forney LJ. Characterization of vaginal microbial communities in adult healthy women using cultivation-independent methods. Microbiology 2004;150:2565-73.

35. Hill JE, Goh SHJ, Money DM, et al. Characterization of vaginal microflora of healthy, non-pregnant women using chaperonin-60 sequence-based methods. Am J Obstet Gynecol 2004 (in press). 


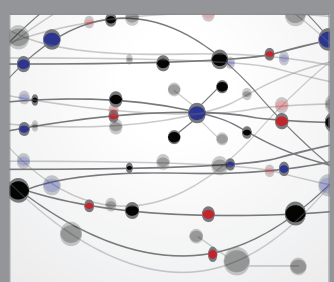

The Scientific World Journal
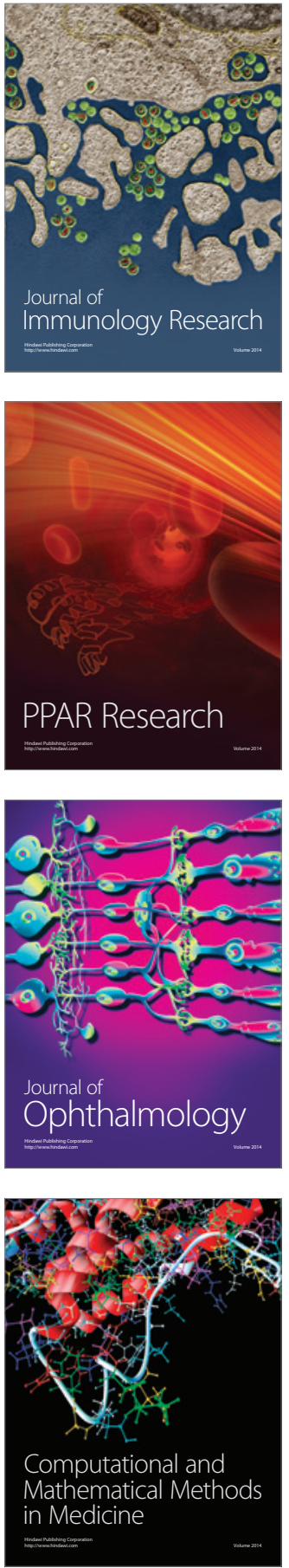

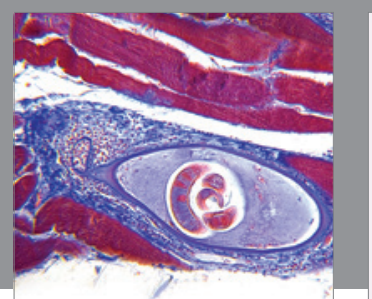

Gastroenterology Research and Practice

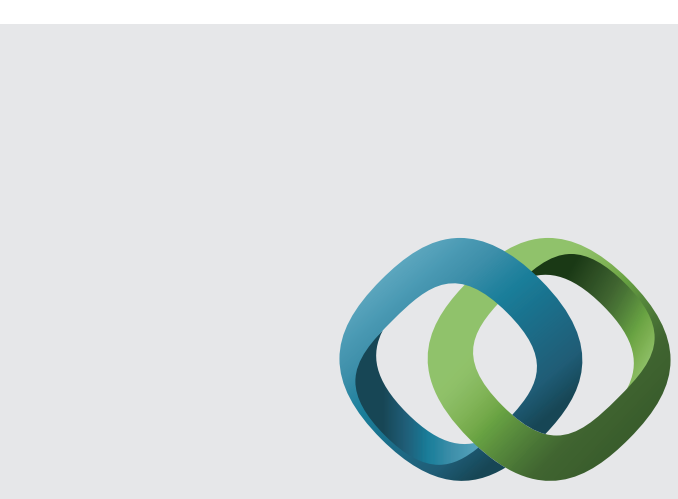

\section{Hindawi}

Submit your manuscripts at

http://www.hindawi.com
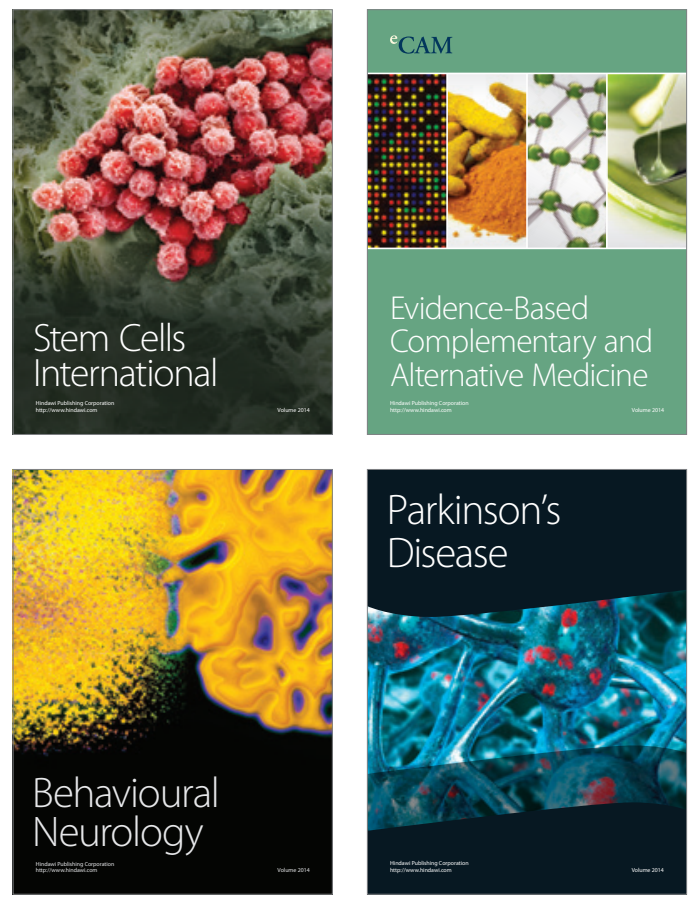
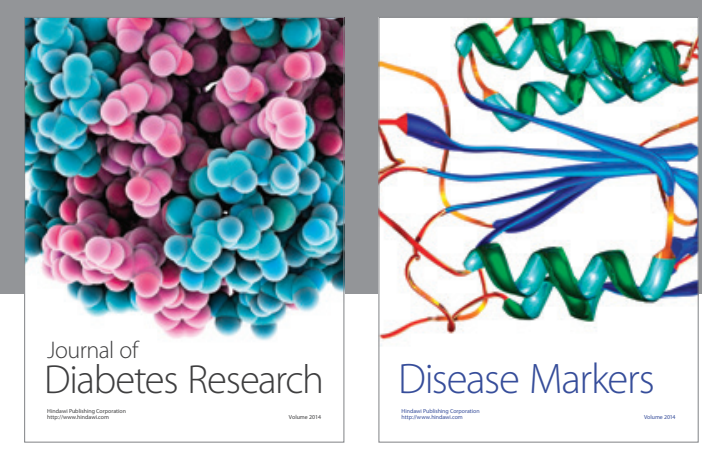

Disease Markers
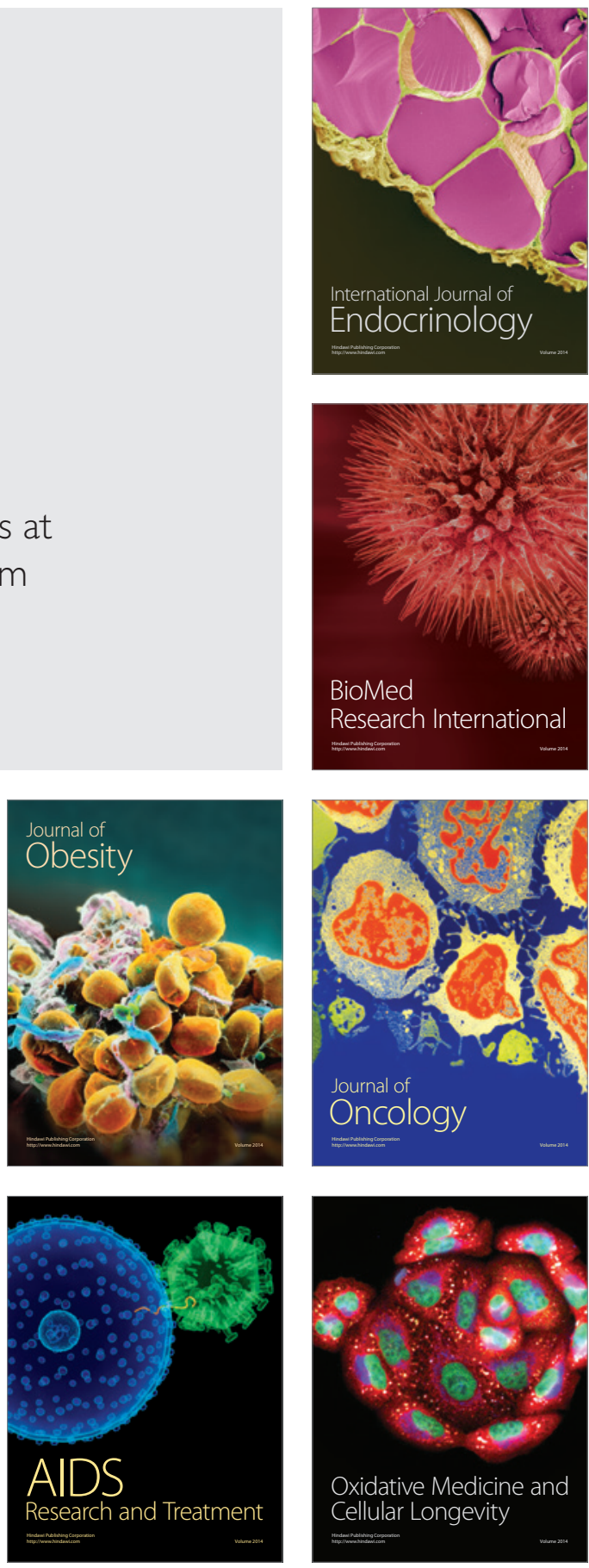